Shot Communication

Bangladesh Agron. J. 2017, 20 (1): 106-108

\title{
SCREENING NON-IMPROVED ZIMBABWEAN SORGHUM LAND RACES FOR RESISTANCE TO WITCH WEED
}

\author{
Onismus Chipfunde ${ }^{1^{*}}$ and Mhosisi Masocha ${ }^{2}$ \\ ${ }^{1}$ Genetic Resources and Biotechnology Institute, Department of Research and Specialist Services, P O Box \\ CY550 Causeway, Harare, Zimbabwe \\ ${ }^{2}$ Mhosisi Masocha, Department of Geography and Environmental Science, University of Zimbabwe, P.O Box \\ MP 167 Mount Pleasant, Harare, Zimbabwe \\ Corresponding Author, E-mail: ochipfunde@gmail.com
}

Key words: Weed emergence, escape hypothesis, Sorghum bicolor, Striga asiatica, Sorghum landraces

Sorghum is an important cereal for food security in semi-arid regions of the world (Mukarumbwa and Mushunje 2010). Semi-arid regions are characterized by frequent droughts leading to crop failure. In addition to drought, sorghum production in the smallholder farming sector in Sub-Saharan Africa can be undermined by the parasitic witch weed Striga asiatica (L.) Kuntze (Stroud, 1993). S. asiatica parasitism can cause cereal yields to drop by as much as $60 \%$ hence it poses a threat to food security (Mabasa, 1993). The aim of this study is to screen sorghum landraces for $\mathrm{S}$. asiatica resistance and test the escape hypothesis through a controlled in a pot experiment. A pot experiment was established on 1 March 2013 at the Henderson Research Station in Zimbabwe. It is situated in agro-ecological region II of Zimbabwe. The annual average rainfall is $864 \mathrm{~mm}$. Mean annual temperature is $21{ }^{\circ} \mathrm{C}$ (Mujere and Mazvimavi, 2012). The dominant soil type is red clay loam belonging to the fersiallitic group (Wulff et al. 2002). Four sorghum (Sorghum bicolor) landraces consisting of two early maturing and two late maturing varieties were obtained from the National Genebank in Harare for this experiment. The early maturing landraces were Tsveta and Nhongoro while the late maturing landraces were Musoswe and Khaki. The biological characteristics of these landraces including days to $50 \%$ flowering is shown in Table 1.

Table 1. Biological characteristics of four Zimbabwean sorghum landraces used in early maturing landraces compared to late maturing landraces.

\begin{tabular}{lccccc}
\hline $\begin{array}{l}\text { Sorghum } \\
\text { landrace }\end{array}$ & $\begin{array}{c}1,000 \text { seed } \\
\text { weight }(\mathrm{g})\end{array}$ & $\begin{array}{c}\text { Days to } \\
50 \% \\
\text { flowering }\end{array}$ & $\begin{array}{c}\text { Maximum } \\
\text { height }(\mathrm{cm})\end{array}$ & $\begin{array}{c}\text { Number of } \\
\text { tillers }\end{array}$ & $\begin{array}{c}\text { Head width } \\
(\mathrm{cm})\end{array}$ \\
\hline Tsveta & 30.1 & 78 & 250 & 3 & 7 \\
Nhongoro & 17.2 & 89 & 310 & 3 & 4 \\
Musoswe & 18.9 & 95 & 335 & 4 & 6 \\
Khaki & 34.4 & 97 & 260 & 6 & 7 \\
\hline
\end{tabular}

Source: Genetic Resources and Biotechnology Institute, 2009.

The experimental units were four different sorghum land race plants grown under natural light with S. asiatica infection and the (uninfected) control. The experiment was conducted in randomized complete design with 6 replications. A total of 48 plastic pots with a volume of 5 litres were used for this experiment. Half of the pots were filled with $S$. asiatica infected sandy soil while the other half was filled with uninfected sandy soil. To infect the soil with $S$. asiatica, the top $5 \mathrm{~cm}$ of the soil in the pot was mixed with 0.09 grams of $S$. asiatica seed (IITP,1997). In each pot, 20 
Screening Non-Improved Zimbabwean Sorghum Land Races for Resistance to Witch Weed

sorghum landrace seeds were obtained from the National Genebank . After emergence, the plants were thinned to one plant per pot. All experimental units were fertilized at a rate of 2 grams per pot with Compound D (that is, 8\% nitrogen, 14\% phosphate and 7\% potassium) as the basal dressing followed by top dressing fertilizer at the rate of 2 grams per pot of ammonium nitrate (34.5\% Nitrogen) 3 weeks after planting. A second top dressing was applied at the start of the $5^{\text {th }}$ week from planting at the same rate as the first top dressing. Plant height was measured at the end of each week for 10 weeks and was analyzed using repeated measures to test whether the interaction of time and $S$. asiatica infection had a significant effect on the vegetative growth of the early and late maturing sorghum landraces. A $t$-test was used and statistical analyses were done by using STATISTICA at 5\% level of significance.

Table 2. Variation in dry biomass yield (g) between four Zimbabwean sorghum landraces grown in Striga asiatica infected soil and uninfected soil

\begin{tabular}{lccccc}
\hline Sorghum landrace & Treatment & Control & t-value & $\mathrm{df}$ & $P$-value \\
\hline Tsveta & $18.4 \pm 9.7$ & $15.4 \pm 6.6$ & 0.51 & 10 & 0.62 \\
Nhongoro & $9.5 \pm 8.8$ & $12.7 \pm 4.6$ & 0.64 & 10 & 0.54 \\
Musoswe & $4.8 \pm 3.7$ & $4.3 \pm 3.8$ & 0.19 & 10 & 0.85 \\
Khaki & $1.4 \pm 0.7$ & $8.7 \pm 5.1$ & 2.46 & 10 & 0.04 \\
\hline
\end{tabular}
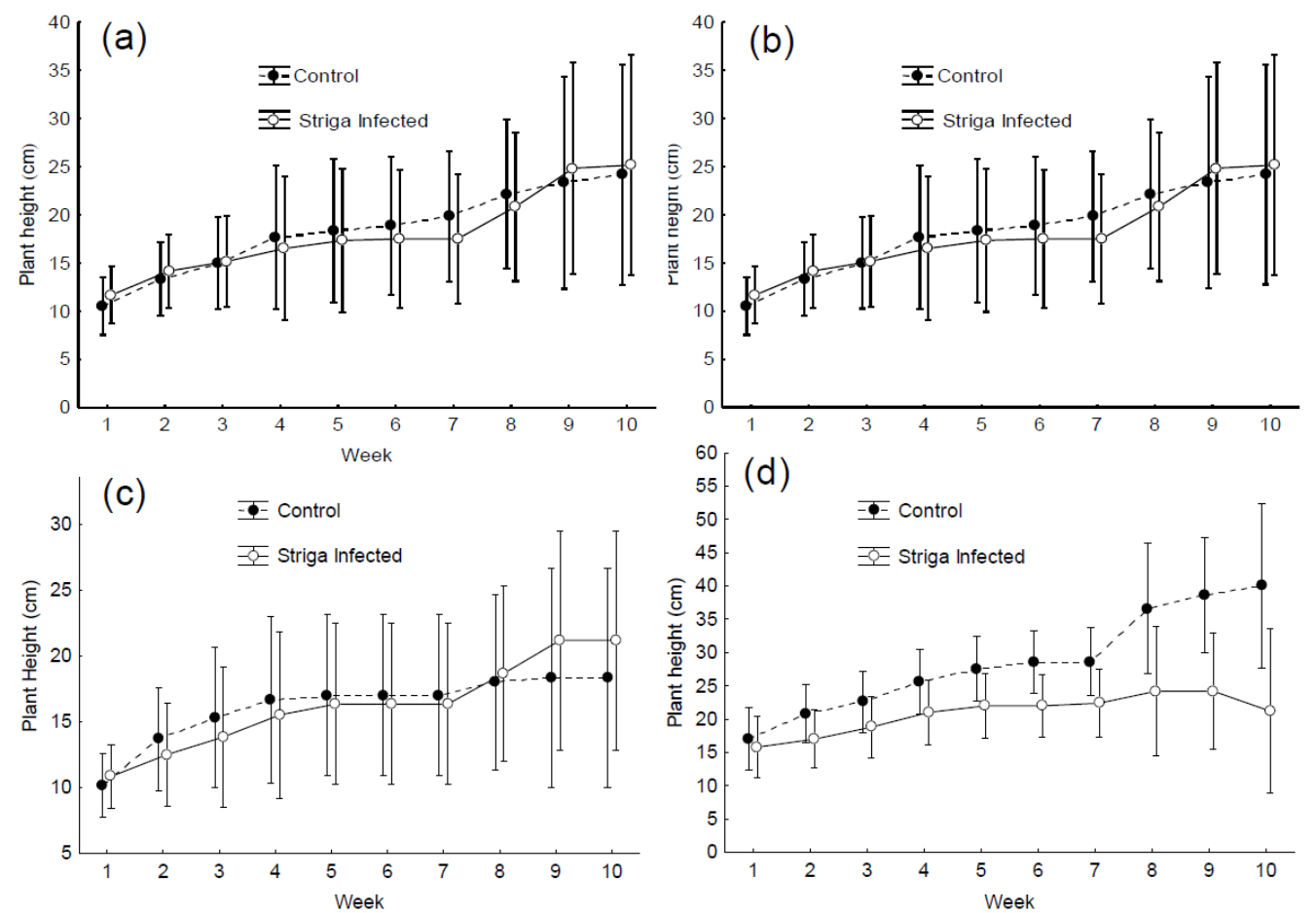

Fig. 1. Effect of Striga asiatica infection on vegetative growth rate of two early maturing sorghum landraces, Tsveta (a) and Nhongoro (b) and two maturing sorghum landraces Musoswe (c) and Khaki (d) grown in S. asiatica infected soil and uninfected soil (control) for 10 weeks. 


\section{8}

\section{Onismus Chipfunde and Mhosisi Masocha}

Control plants from two early maturing landraces (Tsveta, Nhongoro) and one late maturing landrace (Musvoswe) grew faster than the treatment group during the first 8 weeks of the experiment (Figure $1 \mathrm{a}-\mathrm{c}$ ). However, these differences in height growth were not significant. By contrast, the vegetative growth of one late maturing landrace (Khaki) was significantly suppressed by $S$. asiatica Fig. 1d). The results for biomass yield followed a similar pattern. $S$. asiatica infection did not significantly reduce the biomass yield of two early maturing landrace and one late maturing landrace (Table 2) but for Khaki - a late maturing variety, the mean yield for the treatment group was eight times lower than that of the control. Two early maturing landraces and one late maturing landrace used in this study appear to be resistant to $S$. asiatica parasitism. Only one late maturing landrace (Khaki) was sensitive to $S$. asiatica infection during the vegetative stage of growth. These results provide partial support to our hypothesis and imply that Khaki is not a suitable candidate for development of $S$. asiatica resistant sorghum varieties. The growth suppression observed in this landrace confirm the findings of a previous study done in Tanzania where $S$. asiatica significantly reduced both vegetative growth and shoot biomass in several scientifically improved sorghum varieties (Makoko and Sibuga 2003).

This study reveals that early maturing Zimbabwean sorghum landraces tend to be more resistant to $S$. asiatica parasitism compared to late maturing ones. It has identified three scientifically unimproved Zimbabwean sorghum landraces that could be introgressed into commercial sorghum varieties to develop new sorghum varieties with a high resistance to $S$. asiatica parasitism.

\section{References}

IITP (International Institute of Tropical Agriculture). 1997. Striga Research Methods-A manual. Second edition. International Institute of Tropical Agriculture, Ibadan, Nigeria.

Mabasa, S. 1993. The Status of Striga Control Research and Extension in Zimbabwe. In: Proceedings, Third general workshop of the Pan-African Striga Control Network. p 131

Mabasa, S. 1996. Screening sorghum cultivars for resistence to witch weed (Striga asiatica) in Zimbabwe. in Proceedings of the SADC/ ICRISAT regional sorghum and pearl millet workshop. Plenum Press, New York, London, Gaborone, Botswana. Pp 201-209

Makoko, B. R. and K. P. Sibuga. 2003. Preliminary screening of sorghum (sorghum bicolor) genotypes for tolerance/resistance to Striga asiatica. In: African Crop Science Conference Proceedings. African Crop Science Society, Uganda. Pp126-132

Mujere, N. and D. Mazvimavi. 2012. Impact Of Climate Change On Reservoir Reliability. African Crop Science J 20:545-551.

Mukarumbwa, P. and A. Mushunje. 2010. Potential Of Sorghum And Finger Millet To Enhance Household food Security In Zimbabwe's Semi-Arid Regions. Joint 3rd African Association of Agricultural Economists (AAAE) and 48th Agricultural Economists Association of South Africa (AEASA) Conference, , Cape Town, South Africa.

Stroud, A. 1993. Control of weeds. Pages 172-187 in Dryland farming in Africa Macmillan Press, Hong Kong: Technical Centre for Agriculture and Rural Co-operation. 